MedieKultur | Journal of media and communication research | ISSN 1901-9726

Debate

\title{
Debunking public service? \\ Meta-academic and personal reflections from inside the Swedish Public Service Broadcasting Commission
}

\section{Pelle Snickars}

MedieKultur 2016, 61, 162-177

Published by SMID | Society of Media researchers In Denmark | www.smid.dk The online version of this text can be found open access at www.mediekultur.dk

\section{Astract}

During the last half of 2015, a number of Swedish publishing and broadcasting companies-Bonnier, Schibsted Sweden, Mittmedia, Bauer Group - agreed to fund and establish a national Public Service Broadcasting Commission. The purpose was to initiate a public debate about the behaviour and operation of Swedish public service broadcasters-in particular, how they affected the commercial media market, and generally, to discuss the role of national public service broadcasting in a networked media environment. I was a Commission member, and this article describes the background, debates and proposals put forward by the Commission. On one hand, it focuses the work of the Commission with an emphasis on the different public debates the Commission stirred. On the other hand, the article will in a meta-scholarly fashion elaborate on the academic tradition of doing scholarly work focused on public service in Sweden. A recurrent notion in the article is hence meta-academic. Importantly, the article stresses the scholarly bias in favour of public service that is usually present within this tradition (primarily emanating from the field of political communication). Thus, the article is devoted to various debates surrounding the work of the Commission and the role of academics within these discussions (including myself). Finally, the article presents a few thoughts about what it might mean for academics to be (or become) lobbyists.

\section{Keywords}

Swedish Public Service Broadcasting Commission, Media Policy, Academics as Lobbyists 
For a while in August 2016, the major news story dominating Swedish media-about other Swedish media-was inside information from a recent board meeting of the media group Mittmedia at Arlanda airport in Stockholm. According to rumours, Mittmedia, one of Sweden's largest media groups with almost 30 local newspapers, might cut editorial services by 75 percent in the coming year and, as a consequence, leave almost 500 local journalists unemployed. In a small country like Sweden, this news was outrageous, potentially affecting almost a million local readers. The media scoop was published by Dagens Nyheter (Delin, 2017); and, as expected, the Swedish Minister for Culture and Democracy, Alice Bah Kuhnke (from the Green Party), was interviewed. She stated that Swedish media and, especially, local newspapers seemed to be moving towards "the edge of a cliff". I did "not sleep well at all", the Minister asserted when the reporter talked to her the day after the Mittmedia news became public (Jones, 2016).

Heading the board of Mittmedia is Jan Friedman. After reading about the sleepless Minister, he published an "open letter" in Dagens Nyheter: "Dear Alice", Friedman began, subscribers within the private media sector are "diminishing and aging, while advertisers prefer other channels [than local newspapers], especially foreign-owned ones as Google and Facebook." Overall, most "local media companies display diminished margins", he lamented. But you could help us, Friedman stated, addressing the Minister: you "own yourself a toolbox [with] four tools that would really make a difference." Friedman, then, urged the Minister to reconstruct the contemporary Swedish press subsidy system and hoped this would be the case when the ongoing Swedish Media Inquiry (Medieutredningen)_initiated by the Swedish Government in May 2015-would present their long awaited proposal in November 2016. Friedman also argued for the abolition of the Swedish advertisement tax (a peculiar tax on only print media advertising revenues) as well as the strikingly similar print VAT, both of which cause great financial troubles for local newspapers.

The point I want to make with this introduction, however, is that Friedman's major concern was Swedish public service-particularly, at the regional and local level. It was, in fact, the number one tool for the Minister to reconsider. Traditionally, both Sweden's Television (SVT) and Radio Sweden (SR) - which are linked entities but remain two separate institutions-are regionally located across Sweden at various places. Local public service, Friedman told the Minister, triggered competition; but, more often, it has proven "counterproductive". Above all, Friedman asserted, it is "commercially challenging to meet part of SVT's and SR's free online services, while trying to make editorial investments and create tempting terms for paid news activities in a digital world." If even local news is free of charge on the air waves, via cable and/or on svt.se or sr.se-why on earth should listeners, viewers or users in the middle of Sweden pay Mittmedia for the same content? Friedman, thus, urged the Minister to pay attention to this matter and stop ignoring the "increased negative market impact of public service" (Friedman, 2016). 


\section{The media market strikes back}

Jan Friedman's open letter-both friendly and sarcastic in tone-to Minister Alice Bah Kuhnke is but the latest news item in a seemingly never-ending media discussion about Swedish public service broadcasting. The issue has naturally (and historically) been debated before. But, during the last decade (mainly due to the effects of digitisation), the discussion has become more intense. As demonstrated by a rapidly increasing number of articles in the Swedish Media Retriever Database, a search for "public service" in 2005 generated 1,100 articles-ten years later, the number was 2,700 (Media Retriever, 2016). Friedman's counterproductive argument, i.e., free public service content versus paid digital subscription models, has been the epicentre of the debate. The private media sector in Sweden (as elsewhere) has repeatedly stressed the impossibility of competing commercially with free media.

For years, however, Swedish media politics tended to neglect the issue. As a consequence, when the government released the latest Swedish Governmental Official Report (SOU) on public service broadcasting in 2012, Nya villkor för public service (SOU 2012:59), it was criticised harshly by the commercial media sector. The report displayed numerous deficiencies; and, in their official remittance to the government, TV4 (Sweden's major commercial television channel) even stated that it was so poorly investigated and researched that the report could not form the basis for any political decision about any new terms for public service. Lars Nord, a media and communication studies professor at the Mid Sweden University, was the academic expert on the commission, important for the argument in this article. Åsa Jamal, (then) Head of Communications at TV4, even stated that, "primarily, the analysis of SVT's market impact is missing. Unless the government acknowledges it and demands improved reporting so that it becomes clear how to follow and investigate what SVT broadcasts and what funding looks like, the Official Report simply runs the risk of becoming a drop in the ocean" (Jamal, 2012).

In general, commercial and private media groups in Sweden agree that public service broadcasting has an important function within the national media landscape. At the same time, the trend in recent years has made it all too apparent that public service media-content from SVT and SR (but also including UR, the Swedish Educational Broadcasting Company) is both broadcast and Internet-based, spanning basically all media modalities-are increasingly competing with commercial players (in various ways). Public service media, in short, undermine the latter's ability to establish and conduct viable, competitive business models within a transformed media market. In December 2013, the Swedish Government finally commissioned the Swedish Press and Broadcasting Authority-which supervises and supports diversity and accessibility within press, radio and television-to investigate how public service media "affected the media market regarding, for example, competition and market development in general" (Swedish Ministry of Culture, 2013).

The Press and Broadcasting Authority conducted their work during 2014 (and the first half of 2015). However, rumours soon began to circulate that their report would indi- 
cate that public service media did not particularly affect the commercial media sector. The gossip proved to be correct when a first version of their report was published in May 2015 - and, when the final report was presented, it was filled with evasive and puzzling formulations stressing that within the "the nature of public service" lies an inherent influence and impact on commercial media; "such effects may be regarded as expected". According to the report, the chief pressures and impingements on the media market, however, were not caused by public service media but, rather, by contemporary macro factors such as "digitisation and globalisation." Then again, the "overall picture of public service broadcasting operations is that they basically have a positive impact on the media market." Importantly-particularly, with respect to the argument in this article-the report referred to academic media research that sustained such arguments, research that originated from the Mid Sweden University by media professors Lars Nord (again), Jesper Strömbäck and Ingela Wadbring (Swedish Press and Broadcasting Authority, 2016).

As a consequence, during the summer of 2015, a number of Swedish commercial publishing and broadcasting companies took action. On the one hand, they wanted to discuss (and, to some extent, dispute) the claims made by the Swedish Press and Broadcasting Authority in their report. On the other hand, they wanted to initiate a public debate about how the behaviour and operation of Swedish public service broadcasters affected the commercial media market and the role of public service broadcasting in a networked media environment-in short, what is and what should be the nature and mission of Swedish public service? During the early autumn of 2015, the commercial organisations-Bonnier, Schibsted Sweden, Mittmedia, Bauer Group and Tidningsutgivarna (Swedish Media Publishers' Association) - agreed to fund and establish a national Public Service Broadcasting Commission, Public service-kommissionen (in Swedish). Somewhat later, the Modern Times Group (owner of, for example, TV3 and Viasat) also joined. In essence, all commercial media in Sweden stood behind the initiative.

The basic idea was simple: public service broadcasters have a strong position in Sweden. Yet, their role, actual practise and working conditions have, by and large, been formulated by themselves (based on appropriation directives issued by the Swedish Government). As independent institutions, SVT and SR have been able to decide on their own strategies and daily operations. In addition, academic research on public service in Sweden has often reinforced such a frame of reference methodologically, since it usually deploys in-depth interviews with leaders at these institutions, who (so to speak) then reinforce an established self-image (Larsen, 2011; Nord \& Grusell, 2012).

As stated, the premise of the Commission was that public service increased negative market impact, but the job of the Commission was also to carry out an analysis of the very idea of public service media in a digital environment. Hence, in a globally networked media environment-characterised by an abundance of content-the task of public service media ought to be reformulated. Five commissioners were selected. The work was led by the chair, Gunnar Strömblad, who was previously CEO for Schibsted, Sweden, as well as the 
newspapers Aftonbladet and Svenska Dagbladet during the 1980s and 1990s. Other members included Hans-Gunnar Axberger, professor in constitutional law at Uppsala University (and, arguably, the leading Swedish media law expert), as well as Agneta Dreber, former Chair of Radio Sweden (between 2010-2014) and a former member of the Swedish Press Ombudsman and Press Council (independent bodies that deal with complaints about the editorial content of newspapers, magazines and their websites). The fourth person on the Commission was Mikaela Valtersson, a former member of the Swedish Parliament and economic spokesperson for the Green Party. I was the fifth member.

\section{A commissioner's confession}

As a media studies professor-with the profile of a public intellectual in Sweden, debating (over the last decade) various disruptions caused by the 'digitisation of media' in leading Swedish newspapers such as Svenska Dagbladet and, more recently, Dagens Nyheter-I have done scholarly work on public service issues from an historical and a digital perspective (Snickars, 2012, 2014). My background is not in media and communication studies, nor have I done work within the tradition of political communication or news journalism that has, arguably, dominated research on Swedish (and Scandinavian) public service (Larsen, 2014; Carlsson, 2013; Nord \& Grusell, 2012). My academic profile is different. I am humanistic media scholar and do most of my work at the moment in the digital humanities (working with different digital methods) - I am not a social science media scholar.

I am stressing my background because a recurrent notion in this article is meta-academic. Naturally, I am aware of the problem of using myself as an object of study. Yet, I believe there are, at least, a few academic insights to be gleaned from my experiences. On one hand, my article will describe the work of the Swedish Public Service Broadcasting Commission in which I took part last year with an emphasis on the different public debates the Commission stirred. On the other hand, the article will also elaborate on the academic tradition of doing scholarly work focused on public service in Sweden-and, importantly, the bias in favour of public service that is usually present within this tradition (primarily emanating from the field of political communication). The article is devoted to the various debates surrounding the work of the Commission as well as the role of academics within these discussions. Finally, the article presents a few thoughts-in the form a self-reflection-on what it might mean for academics to be (or become) lobbyists.

I have described the background of my fellow commissioners in detail. I have done so not simply because of their impressive CVs but to indicate the truly professional nature of the Commission. According to Thomas Mattson, the editor-in-chief of Expressen (Sweden's second largest tabloid), the members of the Commission were "highly respected and well placed to speak up" (Matsson, 2016). Yet, as it will become apparent in this article, my colleagues-especially, from media and communication studies within the Swedish academy-thought otherwise. Due to its commercial nature, for example it was suggested, and 
even explicitly claimed, that we commissioners were all corrupt. Our opinions had been bought, and a few media professors even stated that we used the "official notion of a commission under cover" (Pollack et al., 2016).

Our Commission was not issued by the Government-it was initiated by the commercial Swedish media sector, which was dissatisfied with the lack of attention (regarding the relationship between commercial and public service media) from academic research and the present Swedish Media Inquiry (which is a governmental commission). The purpose of the ongoing Media Inquiry has been to investigate the possibilities of a sustainable Swedish media policy for the future and "submit a proposal for how to design new media policy tools" (Committee Directive, 2015) - albeit (initially) without looking at the role of public service institutions. Given previous media policy debates, these directives upset the commercial media sector and, more or less, became the reason for launching the Public Service Broadcasting Commission.

As a matter of fact, the woman running the governmental Media Inquiry, Anette Novak-CEO at the Interactive Institute Swedish ICT-repeatedly refused to meet with our Commission (and so did all representatives from both SVT and SR). In addition, during the spring of 2015, I was asked as a media scholar to contribute an article, which Nowak later decided to censor, to a research anthology (linked to the Media Inquiry). Since I was part of the Commission, I was a biased researcher-and, consequently, was not allowed to contribute to the book. I published a news item on the matter (Snickars, 2015b); Nowak did not reply. It apparently made no difference that my article was written before I joined the Commission, nor that it had nothing to do with public service at all (the topic was data brokers and personal data consumption).

I mention these personal details because I want to stress the particular academic environment in which public service is currently researched and debated-at least, in Sweden. During my work within the Commission, in fact, I have more than once felt that there is a dubious symbiosis between the Swedish media scholars who do work on public service and the very institutions they are studying. It is hard to prove empirically, let alone pinpoint in detail. But research around news consumption and "news avoidance" has often tended to have a public service bias (Shehata \& Wadbring 2015; Strömbäck, Djerf-Pierre \& Shehata, 2013) - which, importantly, has been used to sanction and legitimise the whole institution of public service. That is, research within the particular field of political journalism is used as a pretext-particularly, within public discussion—for media research simply to endorse public service.

I do not have a personal agenda as, say, a conservative, right-wing scholar seeking drastically to reduce and restrict public service for ideological reasons. I am a fairly neutral media scholar-with a background in the library sector (as Head of Research at the National Library of Sweden), which has a number of similarities with public service. Given my previous work on the digitisation of media and culture within the heritage domain, it seemed interesting to think about and reconsider the idea of public service as well. That 
was my primary reason for joining the Commission. As a commissioner, I received a fee of 60,000 Swedish crowns (approximately $€ 6,000$ before tax), equal to a month's salary. The entire budget of the Commission was approximately $€ 250,000$. All these figures were openly available right from the start at publicservicekommissionen.se/. It was also stated online that the Commission secretariat was staffed by the PR firm of Paues Åberg Communications, which took responsibility for project management, the production of reports, media relations and administration. In many ways, the work Paues Åberg Communications performed resembled the way an official governmental commission would function. Finally - for complete transparency and clarity in my argument - the purpose of the Swedish Public Service Broadcasting Commission was to stir both a public and a political debate about the role of Swedish public service broadcasters. Nevertheless, the Commission was a lobby group, funded by the major commercial media conglomerates in Sweden-yet, with a crystal clear mandate to work independently within a given framework.

\section{Commission activities \& debates}

The role of the Commission was to examine critically, debate and, possibly, create a public service broadcasting model with a clearer mission - for example, with fewer media market distortion effects-or, as it was stated in the final report from the Commission, the "task has been to carry out a wide-ranging analysis as to how public service broadcasting operates in Sweden today and to present proposals for future public service broadcasting operating models" (Public Service Broadcasting Commission, 2016). A website was set up with a 'mission' and 'terms of reference' (also in English) stressing, in particular, that the Commission would "investigate whether there are any issues with the current definition, function, regulatory framework and oversight of public service broadcasters. Furthermore, the Commission will deal with questions as to the future form of public service broadcasting against the background of the rapid changes that are occurring in the media environment" (About the Commission, 2016).

During eight months of work, we commissioners had approximately ten meetings at which we discussed, for example, the structure of Swedish public service (and the clarification of institutional roles), governmental regulations (or the lack of them), public service market impact (and examples thereof), and how public service ought to be conceptualised anew in a networked society. At one of the meetings, I raised the issue of whether it is reasonable to stipulate that all content transmitted by Sweden's Television and Radio Sweden should become public service by default-especially in relation to similar 'quality content' on other media channels? The Eurovision Song Contest, for example, was held in Stockholm in 2016; it was organised by SVT with an internal budget of more than 10 million Euro plus sponsored funding of an undisclosed sum - was it public service content? McLuhan seemed to be right with respect to public service; the medium literally defined the message. The broadcaster was everything-or, as Mittmedia journalist, Gunilla Kindstrand wittily 
remarked in 2014, "a greasy barbecue tip at SVT always has a greater magnitude of public benefit than independent journalism from a local newspaper" (Kindstrand, 2014).

Hence, within the Commission, we did not only discuss structural transformations and institutional problems related to public service but also the way an abundance of content redefined the very function of public service. In more practical terms, however, during its operation, the Commission also carried out a number of meetings with policymakers, executives, consultants, and major media players in Sweden. We met, for example, with representatives of the government offices, the Swedish Union of Journalists, and a number of political parties. As stated, representatives from the public service broadcasters consistently declined to meet with us. Two major public hearings, however, were organised, one around the transformation of the contemporary media landscape at which the head of strategy at SVT, Jimmy Ahlstrand, gave a talk; as did the CEO of Aftonbladet, Jan Helin (who, a couple of days later, announced that he had been recruited to SVT). The second hearing had an international scope. The purpose was to discuss and relate the Swedish situation to other countries and international experience with the management and organisation of public service, for example, in Britain, Norway and Denmark. Academics were also involved; public service scholar Karen Donders, for example, gave a lecture on public service media in Europe with an emphasis on policy approaches. She stressed that Scandinavian countries in general have had few regulatory requirements (Donders \& Raats, 2015).

In many ways, the second hearing of the Commission was the starting point of an (even more) intense national discussion of public service. In the business daily Dagens Industri, a British and a Swedish journalist argued, for example, that Sweden ought to follow the new directions and directives given to the BBC. "The signal is clear", it was stated; "it is time for a new definition of public service. It ought to be changed from describing an institution towards describing a form of content" (Lloyd \& Bergstrand, 2016). Independently, I published an article in Dagens Nyheter on a similar matter (Snickars, 2016a). In short, my article suggested a number of ways to think about public service in a networked media environment. When the Internet becomes default, it is hardly useful, I stated, "to define public service as only broadcasting or, for that matter, content that SR, SVT and UR transmit". Instead, public service could be thought of as "a general criterion of quality". Another idea of mine was to "imagine public service content (regardless of media modality) that might float freely on the Web applied with a non-commercial CC license." A related idea was to "consider public service as a platform, particularly as a way to deal with competition from American net giants - all in the form of some kind of expanded 'Play services'. The societal impact would be significant," I argued, "and the PS platform could then also be filled with external public service content funded by a PS-trust with clear criteria" (Snickars, 2016a).

A few days later, programme director Robert Olsson (from SVT) replied. He stated that he was not among those "who think that Pelle Snickars [has sold out] his academic authority by allying himself with the heavyweights of commercial media on the so-called Public Service Commission. On the contrary, it is preferable to have a person in this otherwise 
biased group [of commissioners] with a professional experience to examine both one's own and others arguments in a rigid scholarly way." Then again, even though Olsson gave me credit-while also implicitly hinting that I was corrupt-he thought my arguments were basically silly. In short, he stated that SVT remained important today in an altered media landscape since only the institution itself could sustain public service broadcasting's impact on both an individual and a societal level (Olsson, 2016).

In a final reply, I polemically wrote that, within the digital world, "there are no institutions-only functions." Hence, the idea of the future of the public service is "far too important to be reduced to maintaining traditional institutions that mostly belong in the analogue 1900s" (Snickars, 2016b). This line of reasoning was also the one the Commission came to prefer. In fact, the very title of our final report, "The Future of Public Service Broadcasting-From Analogue Institution to a Digital Function", indicates that our proposal was anti-institutional. Interestingly, by pure chance, my (second) article in Dagens Nyheter appeared the same day that the Commission visited the University of Gothenburg's Department of Journalism, Media and Communication (JMG). It is, arguably, the centre of social science media research in Sweden. The so called SOM Institute is located at JMG. It has conducted surveys to collect research data and presented annual trend analyses on public opinion and media habits in Sweden since the late 1980s.

As a scholar who works with various digital methods, I have publicly debated elsewhere the relevance of doing analogue surveys - with self-estimated media usage of made datato understand the transformative consequences and effects of the digital media landscape and particularly so with respect to public service (Snickars, 2015a). In addition, I have elsewhere also argued that one of the reasons significant changes in media research, media policy and the media industry have occurred in recent years is precisely methodological (Hyvönen, Snickars \& Vesterlund, 2016). My purpose is to pinpoint my own different methodological standpoint of doing media studies in relation to most research at JMG in that my own work is digitally grounded.

Arguably, the most arduous advocate for a traditional public service model among media scholars currently working at JMG is Jesper Strömbäck (who previously worked at Mid Sweden University). He is a truly prolific academic and was also the most vigorous defender of the institution of public service in our discussions when the Commission visited JMG. Recently, Strömbäck has done work on various forms on information effects from watching public service and commercial television news. One recent article, "Does Public Service TV and the Intensity of the Political Information Environment Matter?", for example is based on a survey (again) with more than 2,200 respondents. In his article, Strömbäck claims to have detected "stronger knowledge effects from watching public service than commercial TV news" (Strömbäck, 2016a).

In many ways, Strömbäck is an illustrative example of one of the dominant traditions within Swedish media research in which public service is closely linked to-and, sometimes, even equated with-issues of news consumption. Basically, the concern within such pater- 
nalistic research is that growing digital opportunities today for individual media choices cause knowledge gaps-i.e., news consumption and learning in a low-choice public service context is 'better' than in a high-choice media environment. It is worth stressing, however, that the program category of 'news' amounts to about ten percent of Swedish public service media. Hence, it always strikes me (as a media scholar who is not at all interested in news journalism or (traditional) political communication) as peculiar how my fellow academics are so obsessed with news, democracy and public service (Aalberg, 2015) - especially since 90 percent of public service programmes are essentially not about news at all. Personally, I regard public service media as including far more than news-children's programmes, documentaries, drama, sport, film, art and culture for a start.

Then again, from a political perspective, audience news consumption has always been regarded as truly important. In fact, when Swedish public service institutions gradually developed in scale from the mid-1950s onwards, internal research of public service audiences became a vital part of the institutions themselves. The task of the "Audience and Program Research Section" (PUB) at Radio Sweden (which, at the time, also incorporated SVT) was to study public service and audiences. During the 1970s, for example, major projects were initiated to measure public service news penetration within the so-called "information gap project". Essentially, the research ideas were (again) paternalistic, and the project was almost Marxist in its effort to make public service programmes cater to all classes.

Interestingly, a number of researchers working at PUB later became leading proponents of media and communication studies in Sweden (Hyvönen, Snickars \& Vesterlund, 2015). In short, the scholarly tradition of studying news and public service has developed in tandem with the academy and public service institutions-and, until 1993 (the year PUB closed), even inside the latter. Consequently, today, this type of media research-for example, on issues surrounding 'news avoiders', a topic on which Strömbäck has often been publicly quoted in Sweden-often gets picked up by the public service institutions themselves. In his talk at one of the public hearings the Commission organised, for example, Jimmy Ahlstrand from SVT made frequent allusions and references to this type of academic research on news consumption (which, thus, gave it a stamp of approval for the institution of public service). Given the above, it hardly came as a surprise that, when Strömbäck tweeted that his latest article had been published in March 2016 with its claim about the positive knowledge effects of watching SVT's news programme Rapport but not (the commercial) TV4 News-it was retweeted by Hannah Stjärne, the CEO of Sweden's Television (Strömbäck, 2016b).

\section{Beyond the institution-Commission recommendations}

During the spring of 2016, the work of the Public Service Broadcasting Commission was the nexus of national discussions and debates about the role of public service broadcasting in Sweden. Some 200 articles and programmes appeared in Swedish media covering 
the Commission's ideas, its comings and goings. Some were positive-others fiercely negative. When the final report was to be unveiled in Gothenburg in April 2016 at the Swedish MEG16 festival-arguably, the most important annual meeting for Swedish media-the scene was set for another round of animated discussion.

The final report from the Commission has been translated into English (and can be downloaded from the Web at publicservicekommissionen.se/english/). I will, therefore, only summarise its basic arguments. The Commission presented a number of recommendations and proposals to the Swedish Parliament and Government. The Commission firmly stated that it "believed that the current view of public service broadcasting needs to change. Public service broadcasting should be seen as a function, not as an institution." The underlying analyses of the Commission were historically motivated; the original idea to create publicly-financed broadcasters-"limited spectrum, the desire to be able to provide a programming output over the airwaves and the political ambition to control media consumption"-were deemed to irrelevant. Instead, we commissioners envisioned a greater "breadth in public service providers" that would possibly "promote greater media diversity and stimulate innovation, entrepreneurship and creativity across a range of different genres." Since a number of external production companies (nationally as well as internationally) were already producing public service content for both SVT and SR - which, today, buy these productions and transform them into public service-the Commission believed that such a system could be scalable, independent of these institutions.

However, this would only work with a new funding structure in place of the financing of public service production outside of traditional corporations. Regarding funding, the Commission proposed that the Swedish "radio and television license" be abolished and that all media subsidies would, instead, be financed through the normal taxation system and distributed by direct appropriation from the state budget. The usual objection from public service to such proposals has often been that budget appropriation financing might reduce independence and planning certainty. Then again, the Commission noted in the final report that a number of other important public services are today "financed through the budget appropriations process, including the judicial system, higher education and research as well as other state financing of cultural institutions and media"-hence, excluding public service broadcasting institutions would not make any sense.

The new funding structure that the Commission proposed included a number of different components: "1. Support for local journalists to replace the current system of press subsidies that aim to support coverage of local communities by journalists; 2 . A platformindependent public service fund for the production of public service content by journalists across different genres; 3 . A Nordic media fund to support public service productions." To sustain such a new structure, the second proposal was the most important. We commissioners proposed a national operational subsidy for the production of public service content-a kind of public service fund (or trust) - that should be open to any media, production company or independent production project (commercial or not) as long as they 
met certain stipulated criteria. In short, the aim of the PS fund was to "provide support to high-quality public service productions that would not be possible to finance on purely commercial grounds." Above all, the idea was to allow organisations or companies to apply for support for different public service content. It would, then, be "broadcast, displayed or distributed via platforms independent of the three existing public service broadcasting corporations." The Commission also stated that the subsidies should be "time limited, allow for co-financing and be able to be combined with other financing models." In addition, publishers and broadcasters should partake in some kind of system of media ethics. One objection to such a funding system, the final report also stated, is that the State might be regarded as inappropriate to 'judge', say, the quality of journalism. However, similar evaluations are made in a number of other areas-for example, research, film, literature and other cultural subsidies. Therefore, it should be quite "straightforward to create a similar system for public service productions that are made for the public benefit."

Naturally, this also meant that the current Swedish public service institutions would have to be altered, modified-and, ultimately, reduced. The Commission, for example, argued that programme offering at the traditional institutions should in the future be "characterised by quality, impartiality, objectivity, and inclusiveness and should add value to the media market as a whole." Basically, this meant that public service should "abstain from producing programmes, services or formats that independent commercial media organisations already provide." In addition, the Commission stated that we believed there to be grounds for the Swedish Parliament "to clarify that the public service broadcasting corporations have a particular responsibility to provide a basic offering of productions and programmes that are public service in their character" (Public Service Broadcasting Commission, 2016).

\section{Conclusion-Academics as lobbyists?}

One might sum up the proposals from the Commission by simply stating that, since we commissioners truly believed that public service is essentially a societal function (and not an institution), economic resources ought to be transferred from the Swedish public service broadcasting corporations to other forms of national media subsidies. The only valid argument against such a proposal-at least, to my mind-is that the national institution of public service broadcasting would gradually diminish in importance. According to annual reports published by SVT and SR, it is only by sustaining a major "impact" that their national position of societal importance can be upheld and legitimised. In the last annual reports from SVT (2014 and 2015), the notion of "impact" has, in fact, been a header of its own. "Only through a major impact can SVT maintain its position as a democratic tool. To retain this impact during the great upheavals in the media market is one of the biggest challenges for the company" (SVT Annual Report, 2015). They might be right, and the suggestions from the Commission would inevitably lead to a decrease in the impact of public 
service broadcasting. Still, we commissioners sincerely believed that it is the content that matters-not the broadcaster-and particularly in a digital media environment.

As could be expected, the public service institutions SVT, SR and UR did not particularly like these anti-institutional ideas and suggestions. A heated national debate followed, which this article cannot describe-with the exception of one final academic response (again, suggesting the dubious relationship between some media scholars and public service institutions). One important consequence of the work of the Commission during the spring of 2016, however, was that, just two weeks before the Commission released its final report at MEG16, the ongoing national Media Inquiry sent a memo to the Swedish Minister for Culture and Democracy, Alice Bah Kuhnke, entitled: "Publicly funded media-issues that ought to be investigated for the next licensing period". The memo stated that the present Media Inquiry did not have the mandate to analyse and suggest recommendations regarding Swedish public service broadcasting but that it had the right to "point out issues that need to be further investigated before the next licensing period" (Swedish Media Inquiry, 2016) - and the relation between public service broadcasters and the commercial media market was definitively such an issue. In many ways, this memo was an earlier version of Jan Friedman's "open letter" to the Minister. At the time of this writing, the Swedish Government is dealing with this memo. Suffice to say that, even though Anette Novak and the national Media Inquiry refused to meet and discuss the role of public service broadcasting and its relation to commercial media with the Commission, our work undoubtedly caused the Media Inquiry to act.

Nevertheless, I want to finish with a meta-academic comment centred on a debate article in Svenska Dagbladet, written by three Swedish media and communication scholars in late April 2016 (Pollack et al., 2016). The reason for their article was the memo around "Publicly funded media" from the Media Inquiry as well as the final report from our Commission. It might not come as a surprise that one of the authors was Lars Nord, a scholar whose academic output can only be described as pro-institutional regarding public service; the others were Ester Pollack and Sigurd Allern at JMK, Stockholm University. Basically, their article argued that commercial media was a nuisance; "critical journalism" needed to be sustained; and "media and journalism cannot be described as actors" in a market because they are a vital necessity for democracy. Without going into any form of dialogue with the PM or the proposals from the Commission, the authors stated: "Research shows that free and independent media is a cornerstone of democratic infrastructure ... strong public-service institutions with editorial independence from the government and parliament is a central part of this infrastructure."

As stated before, my own work (as a media studies professor) within the Commission as well as that of my academic colleague, media law expert professor Hans-Gunnar Axberger, were imperceptible and not recognised as academic input. We were simply corrupt; our opinions had been bought. "It is hardly surprising that media companies, including media groups with large surpluses, fervently argue for changes in media policy in a direction that 
is favourable to themselves and their owners", Pollack et al. asserted. Their article made no reference to the actual problems between the commercial media sector and public service broadcasting or to the Commission's proposal to shift emphasis from institution towards function (Pollack et al., 2016). In fact, towards the end of the article, Pollack et al. suddenly seemed aware that their article could be understood as simply defending existing conditions - as if digitisation had never happened - which they assured it was not.

I sometimes ask myself how media and communications scholars, displaying a limited understanding of how commercial media works, are capable of analysing any of the current transformations caused by digitisation. If scholarly media research is to remain at least modestly relevant for media policy, it needs to be able to grasp the different positions and frames of reference within the rapidly transforming media landscape-particularly, regarding public service media. Otherwise, research runs the risk of referring to and arguing for the status quo. Academics, then, become lobbyists; research becomes ideologically biased-and even paternalistic in terms of public service-albeit without noticing it. In fact, if one compares a number of Swedish media scholars who have done work on public service (some of whom are mentioned in this article) with the actual subjects they are studying - i.e., the journalists and institutions themselves - the latter are far more dynamic in their understanding of current digital transformations and the role of public service broadcasting. Arguably, this has to do with the concept of roles in which it is completely natural for a journalist (or someone working within media in general) to shift perspectives depending on employment. The present CEO of SVT, for example, Hannah Stjärne, was for years CEO of the commercial media group UNT. And, as stated, during the spring of 2016, she recruited Jan Helin - one of the nation's most knowledgeable media strategists, and CEO at Aftonbladet-to become one of her closest collaborators at SVT. Similarly, Radio Sweden has had leading proponents and media strategists recruited from the commercial sector-for example, Martin Jönsson, who was recently hired by the newspaper Dagens Nyheter.

I was recruited by the commercial media sector in Sweden to be a commissioner in the Public Service Broadcasting Commission. I was picked not because of my lavish production of academic articles on public service but for my broader, idea based and varied work on contemporary digitisation of culture and media (I think). Naturally, since the commission was a lobby group - but with a mandate to work independently - the commercial media conglomerates behind the Commission did not want academics who were biased in favour of public service broadcasting. I was not thought to be one of those-but others definitively were. Hence, at least from one vantage point, a number of Swedish media and communication scholars are, thus, presently perceived to be prejudiced and partial. If humanistic and social science scholars usually think that they have a reputation of being neutral observers-the present article is gentle reminder that this is not the case. 


\section{References}

Aalberg, T. (2015). Does public media enhance citizen knowledge? Sifting through the evidence. PERC, 13. Retrieved from: http://www.perc.org.uk/perc/wp-content/uploads/2015/12/PERC-Paper-13-PublicMedia-and-Citizen-Knowledge-Toril-Aalberg-Dec-15.pdf.

About the Commission (2016). Retrieved from: http://www.publicservicekommissionen.se/english/.

Committee Directive (2015). En mediepolitik för framtiden. Retrieved from: http://www.regeringen.se/cont entassets/37c5138b3218403f8c31bbf1658c4e48/en-mediepolitik-for-framtiden-dir.-201526

Donders, K., \& Raats, T. (2015). From public service media organisations to de-centralised public service for the media sector: A comparative analysis of opportunities and disadvantages. Javnost - The Public, 22(2), 145-163.

Jones, E. (2016, 18 August). Medierna står vid kanten av ett stup. Dagens Nyheter. Retrieved from: http:// www.dn.se/kultur-noje/medierna-star-vid-kanten-av-ett-stup/.

Delin, M. (2016, 17 August). Mittmedias plan kan slå hårt mot lokaltidningar. Dagens Nyheter. Retrieved from: http://www.dn.se/kultur-noje/mittmedias-plan-kan-sla-hart-mot-lokaltidningar/.

Friedman, J. (2016, 23 August). Vi vill inte att du ska ligga sömnlös. Dagens Nyheter. Retrieved from: http:// www.dn.se/kultur-noje/kulturdebatt/oppet-brev-till-kulturminister-alice-bah-kuhnke/.

Media Retriever (2016). Search term "public service". Retrieved from: https://web-retriever-info-com.proxy. ub.umu.se/services/archive/search.

Hyvönen, M., Snickars, P., \& Vesterlund, P. (2015) (Eds.). Massmedieproblem. Mediestudiets formering. Lund: Mediehistoriskt arkiv.

Hyvönen, M., Snickars, P., \& Vesterlund, P. (2016).The Formation of Swedish Media Studies, 1960-1980. Media History (forthcoming).

Lloyd, J., \& Bergstrand, M. (2016, 29 January). Debatt: Byt ut public service-modellen. Dagens Industri. Retrieved from: http://www.di.se/artiklar/2016/1/29/debatt-byt-ut-public-service-modellen/.

Nord, L., \& Grusell, M. (2012). Inte för brett, inte för smalt: Spelet om framtidens public service. Gothenburg: Nordicom.

Jamal, Å. (2012, 11 September). Press release from TV4. Retrieved from: http://tv4gruppen.se/Senaste-nytt/ Senaste-nytt-/TV4-kommenterar-public-service-utredningen/.

Kindstrand, G. (2014, 1 August). Ett flottigt grilltips i allmänhetens tjänst. Mittmedia. Retrieved from: http:// www.helahalsingland.se/opinion/ledare/utgivaren-ett-flottigt-grilltips-i-allmanhetens-tjanst.

Larsen, H. (2011). Public service broadcasting as an object for cultural policy in Norway and Sweden. A policy tool and an end in itself. Nordicom Review, 32(2), 35-47. Retrieved from: http://www.nordicom.gu.se/ sites/default/files/kapitel-pdf/345_larsen.pdf

Larsen, H. (2014). The legitimacy of public service broadcasting in the 21st century. The case of Scandinavia. Nordicom Review, 35(2), 65-76. Retrieved from: http://www.nordicom.gu.se/sites/default/files/kapitelpdf/nordicom_review_35_2014_2_pp._65-76.pdf

Mattson, T. (2016, 10 April). Public service för alla? Expressen. Retrieved from: http://bloggar.expressen.se/ thomasmattsson/2016/04/public-service-for-allap/.

Olsson, R. (2016, 4 February). SVT: Tokig slutsats att internet skulle reducera public services legitimitet. Dagens Nyheter. Retrieved from: http://www.dn.se/kultur-noje/kulturdebatt/svt-tokig-slutsats-attinternet-skulle-reducera-public-services-legitimitet/.

Pollack, E., Nord, L., \& Allern, S. (2016, 24 April). Naivt tro att marknaden räddar journalistiken. Svenska Dagbladet. Retrieved from:

http://www.svd.se/naivt-tro-att-marknaden-raddar-journalistiken.

Public Service Broadcasting Commission (2016). The Future of Public Service Broadcasting - From Analogue Institution to a Digital Function. Retrieved from: 
http://www.publicservicekommissionen.se/wp-content/uploads/2015/11/PSK-160421-The-Future-of-Public-Service-Broadcasting---From-Analogue-Institution-to-a-Digital-Function.pdf.

Snickars, P. (2012). If content is king, context is its crown. View. Journal of European Television History and Culture, 1(1), 34-39. Retrieved from: http://www.viewjournal.eu/index.php/view/article/view/jethc006/6.

Snickars, P. (2014). Digitalism. När allting är internet. Stockholm: Volante förlag.

Snickars, P. (2015a, 10 May). Så trångsynt att man blir mörkrädd. Mittmedia Kultur. Retrieved from: http:// www.op.se/kultur/sa-trangsynt-att-man-blir-morkradd.

Snickars, P. (2015b, 10 December). Medieutredningens censur av min artikel är besynnerlig. Dagens Nyheter. Retrieved from: http://www.dn.se/kultur-noje/kulturdebatt/pelle-snickars-medieutredningens-censurav-min-artikel-ar-besynnerlig/.

Snickars, P. (2016a, 1 February). Så ska public service blomstra i en digital era. Dagens Nyheter. Retrieved from: http://www.dn.se/kultur-noje/kulturdebatt/sa-ska-public-service-blomstra-i-en-digital-era/.

Snickars, P. (2016b, 15 February). Digitaliseringen. Förståelsen för vad internet gör med samhället är för grund. Dagens Nyheter. Retrieved from: http://www.dn.se/kultur-noje/kulturdebatt/digitaliseringenforstaelsen-for-vad-internet-gor-med-samhallet-ar-for-grund/.

Shahata, A., \& Wadbring, I. (2015). A longitudinal analysis of news-avoidance over three decades: From public service monopoly to smartphones. Conference Paper at ICA.

Strömbäck, J. (2016a). Does public service TV and the intensity of the political information environment matter? Journalism Studies (2016 preprint), 1-18. Retrieved from: http://www.tandfonline.com/doi/full/1 0.1080/1461670X.2015.1133253?scroll=top\&needAccess=true.

Strömbäck, Jesper (2016b, 5 March). Tweet. Retrieved from: https://twitter.com/JesperStromback/ status/706157726431363072.

Strömbäck, J., Djerf-Pierre, M., \& Shehata, A. (2013). The dynamics of political interest and news media consumption: A longitudinal perspective. International Journal of Public Opinion Research, 25(4), 414-435 doi:10.1093/ijpor/eds018

SVT Annual Report (2015). Sveriges Televisions public service-redovisning 2015. Retrieved from: http://www. svt.se/omsvt/fakta/public-service/article6846013.svt/BINARY/Public\%20service-redovisning\%202015.

Swedish Media Inquiry (2016). De offentligt finansierade medierna - frågeställningar som bör utredas inför nästa tillståndsperiod. Retrieved from: http://www.medieutredningen.se/wp-content/ uploads/2016/03/PM-om-de-offentligt-finansierade-medierna-23-mars-2016.pdf.

Swedish Ministry of Culture (2013). Uppdrag till Myndigheten för radio och tv att analysera hur radio och tv i allmänhetens tjänst påverkar mediemarknaden. Retrieved from: http://www.radioochtv.se/documents/uppdrag/förhandsprövning/uppdrag\%20analysera\%20ps\%20marknadspåverkan.pdf.

Swedish Press and Broadcasting Authority (2016). Utveckling och påverkan i allmänhetens tjänst, Dnr 13/03001 and 14/01248. Retrieved from: http://www.radioochtv.se/documents/uppdrag/ps\%20 marknadspåverkan\%202014-2015/utveckling\%20och\%20påverkan\%20i\%20allmänhetens\%20tjänst\%20 inkl\%20summary\%202015.pdf.

Pelle Snickars

Professor

Department of Culture and Media Studies / Humlab

Umeå University

pelle.snickars@umu.se 